ISSN 0206-5657. Вісник Львівського університету. Серія біологічна. 2020. Випуск 83. С. 39-48 Visnyk of the Lviv University. Series Biology. 2020. Issue 83. P. 39-48

\title{
БOTAHIKA
}

УДК 582.28(630.580)

https://doi.org/10.30970/vlubs.2021.83.05

\section{ПЕРШІ ВІДОМОСТІ ПРО МІКОБІОТУ НАДВІРНЯНСЬКОГО ЛІСНИЦТВА (ІВАНО-ФРАНКІВСЬКА ОБЛАСТЬ)}

\author{
О. Богославець ${ }^{1}$, А. Атаманчук ${ }^{1}$, В. Джаган ${ }^{2 *}$, М. Шевченко ${ }^{1}$ \\ ${ }^{1}$ ННЦ “Інститут біологї̈ та медицини” \\ Киівський начіональний університет імені Тараса Шевченка \\ вул. Володимирська, 64/13, Київ 01601, Украӥна \\ ${ }^{2}$ Інститут ботаніки імені М.Г. Холодного НАН України \\ вул. Терещенківська, 2, Київ 01004, Украӥна \\ e-mail:veronika.dzhagan@gmail.com
}

\begin{abstract}
У роботі наведено перші відомості про мікобіоту 1-8 кварталів Надвірнянського лісництва, розміщених на схилах гір Городище (598 м н. р. м.) та Потоки (584 м н. р. м.). У результаті проведених досліджень на території зазначеного лісництва виявлено 107 видів грибів і грибоподібних організмів, що належать до 92 родів, 49 родин, 21 порядку, 7 класів та 3 відділів. Усі види наведено для дослідженої території вперше. Особливу увагу приділено грибам, що ростуть на деревному субстраті. Серед них найбільшу кількість видів (68) зареєстровано на деревині бука європейського. Сім видів (Butyriboletus appendiculatus (Schaeff.) D. Arora \& J.L. Frank, Clathrus archeri (Berk.) Dring, Hericium cirrhatum (Pers.) Nikol., H. coralloides (Scop.) Pers., Ischnoderma resinosum (Schrad.) P. Karst., Mutinus caninus (Huds.) Fr., Strobilomyces strobilaceus (Scop.) Berk.) виявилися рідкісними для території дослідження й України загалом. Чотири із них (Clathrus archeri, Hericium coralloides, Mutinus caninus, Strobilomyces strobilaceus) занесені до Червоної книги України, а три види (Butyriboletus appendiculatus, Hericium cirrhatum та Ischnoderma resinosum) - до Європейського червоного списку та червоних списків різних країн. Hericium cirrhatum та Ischnoderma resinosum є індикаторами фітоценозів, що мають природоохоронну цінність. У зв'язку з виявленням рідкісних і созологічно цінних видів грибів, що вказують на значну природоохоронну цінність обстежених фітоценозів, та зі зростанням антропогенного навантаження на досліджуваний лісовий масив обгрунтовано доцільність розширення на його території наявної мережі об'єктів природно-заповідного фонду, посилення заповідного режиму та контролю за його дотриманням. 3 огляду на те, що обстежена територія характеризується значним різноманіттям не лише мікологічних, а й ботанічних, зоологічних і геологічних об’єктів, які потребують охорони, запропоновано створити на всій території масиву регіональний ландшафтний парк «Надвірнянський ліс», що дасть змогу взяти під охорону значну частину Гвіздського структурно-ерозійного низькогір'я, котре поєднує в собі риси як Передкарпатських, так і Гірськокарпатських ландшафтних комплексів.

Ключові слова: види-індикатори, охорона грибів, Червона книга України, заповідна справа
\end{abstract}

Українські Карпати - унікальний природно-історичний регіон, один із найбільших центрів біологічного різноманіття й ендемізму в Україні, тому вже більше ста років ця територія є об'єктом пильної уваги з боку зоологів, ботаніків, мікологів, дослідників та ентузіастів природоохоронної справи. Наслідком такого зацікавлення став, зокрема, досить високий відсоток заповідності Українських Карпат порівняно з іншими природними

(C) Богославець О., Атаманчук А., Джаган В., Шевченко М., 2020 
регіонами України - 12,2 \%, у той час як аналогічний показник для території всієї країни станом на 2012 рік становив 6,5 \% [11]. При цьому варто відзначити значну нерівномірність розподілу територій і об’ єктів природно-заповідного фонду (ПЗФ) в регіоні. Так, на території Гірськокарпатського ландшафтного округу сконцентрована набагато більша кількість об'єктів ПЗФ, ніж у Передкарпатському та Закарпатському. Детальніший розгляд показує явну тенденцію до концентрації заповідних територій у високогірно-полонинських районах за мінімальної заповідності в низькогірних і передгірних. Отже, далеко не всі специфічні й унікальні ландшафтні комплекси регіону перебувають під захистом природоохоронного законодавства. Таким чином, створення нових і розширення наявних заповідних територій $\epsilon$ особливо важливим у низькогірних та передгірних ландшафтних областях [14].

Серед природно-територіальних комплексів (ПТК) Передкарпатського ландшафтного округу особливу увагу привертають острівні структурно-ерозійні низькогір'я, відділені від гір широкими заниженнями рельєфу. Всі вони розміщені в межах Бориславсько-Покутської підзони Передкарпатського прогину та відзначаються домінуванням типових передкарпатських ландшафтних комплексів [14]. За геологічним походженням вони схожі з Покутськими Карпатами, проте мають складнішу будову: схили цих низькогір'їв асиметричніші, а вершини гостріші, тому вони більш заліснені та менш заселені [9]. Таких ПТК в межах Українських Карпат виділяють три: Майданське, Слобода-Рунгурське та Гвіздське [14]. Останнє в літературі також трапляється під іншими назвами (іноді розходяться також і думки щодо його меж) - Надвірнянське [13], БитківськоГвіздське [9] та Міжбистрицьке [6]. У межах цього ПТК розташовані дві вершини Городище (598 м н. р. м.) та Потоки (інші назви - Скала, Гвоздецька Гора, Гвіздецька Гора; 584 м н. р. м.) [4]. На схилах цих гір розміщується лісовий масив, що займає 1-8 квартали Надвірнянського лісництва, підпорядкованого ДП “Надвірнянський Держлісгосп” [13]. За фізико-географічним районуванням цей масив належить до Височинно-передгірної області, підобласті Пригорганського передгір'я, Гвіздського району [14], за геоботанічним районуванням - до Передгорганського підрайону Болехівсько-Берегометського району ялицево-букових лісів [5]. Місцеві деревостани сформовані здебільшого буком лісовим (Fagus sylvatica L.), грабом звичайним (Carpinus betulus L.) та дубом звичайним (Quercus robur L.). Підлісок розріджений, слабо розвинений або зовсім відсутній. Загалом, флора лісництва $є$ репрезентативною для середньогірського поясу Українських Карпат, проте має певну регіональну специфіку, зокрема, своєрідний склад підліску та трав'яного покриву, в якому переважають термофільні види лісостепового характеру [3].

Історія заповідання цього лісового масиву налічує щонайменше 80 років. Так, буковий резерват в урочищі Потоки існував ще у 30-х роках минулого століття. Нині цю територію займає лісовий заказник місцевого значення “Потоки” площею 154,2 га (кв. 2 , $3,5,6)$, який може вважатись одним із найстаріших природоохоронних об'єктів басейну р. Бистриці Надвірнянської [12]. На території заказника охороняються буково-грабові ліси 3 домішкою дуба віком 60-110 років, в підліску яких трапляється берека проміжна (Sorbus torminalis L.) - рослина, єдиним природним місцезростанням якої на Передкарпатті $\epsilon$ цей резерват. Наряду з лісовим заказником "Потоки" на цій території існує кілька менших природоохоронних об'єктів місцевого значення: ботанічна пам'ятка природи “Потоки" (пл. 0,5 га, кв. 6 вид. 5), заповідне урочище “Букове” (пл. 52 га, кв. 5 вид. 5-8, кв. 6 вид. 1, 2), а також заповідне урочище “Городище” (пл. 24,9 га, кв. 7 вид. 7-10, 14-17), створене для охорони природних угруповань за участю Quercus petraea L. на північній межі їхнього ареалу. На території цих об'єктів під охороною перебувають 13 видів рослин і чотири види тварин, занесених до Червоної книги України $[3,13,16]$. На території шостого кварталу (вид. 9) розміщена геологічна пам'ятка природи місцевого значення “Надвірнянські скелі” - найбільше у Свропі відслонення стебницьких відкладів, що разом 
із відслоненнями добротівських верств і слобідських конгломератів, розташованими на території восьмого кварталу, входить до складу об'єкта “Дельта зниклої ріки”, одного з 28 геосайтів транскордонного польсько-українського геотуристичного шляху "Гео-Карпати” $[2,13]$. Урочища Городище та Потоки $є$ популярними місцями відпочинку на природі серед надвірянців і гостей міста. Через лісовий масив прокладені траси для велосипедистів [13].

Слід зазначити, що даних про гриби та грибоподібні організми Надвірнянського лісництва у доступній нам літературі немає. Отже, оскільки зазначений лісовий масив $є$ важливим місцевим осередком біорізноманіття, метою даного дослідження була оцінка його созологічного потенціалу та відповідності між вжитими й необхідними природоохоронними заходами за допомогою встановлення видового складу грибів і виокремлення видів, що мають природоохоронне значення. Особливу увагу ми приділили грибам, що мешкають на деревному субстраті (wood-inhabiting fungi), серед яких кілька видів є індикаторами лісів, що підлягають охороні $[18,19]$.

\section{Матеріали та методи}

Збір зразків на території Надвірнянського лісництва проводили маршрутним методом упродовж вегетаційних сезонів 2018-2020 років. Опис локалітетів, у яких здійснювали збір матеріалу, подано в табл. 1, а карту локалітетів - на рисунку. Потенційні субстрати для грибів (деревина, грунт, листковий і гілковий опад) ретельно обстежували за допомогою лупи. Всі збори супроводжувалися відповідними описами (дата збору зразка, місце збору, тип рослинності в локалітеті, де був зібраний зразок, домінантні види деревних порід, тип субстрату, на якому розвивалися плодові тіла, географічне розташування точки збору тощо).

Таблиця 1

Опис локалітетів 1-8 кварталів Надвірнянського лісництва, в яких проводився збір мікологічного матеріалу

\begin{tabular}{|c|c|}
\hline Локалітет & Місцевість \\
\hline Л1 & $\begin{array}{l}6 \text { кв (48³9’10» пн. ш., 24³4’27» сх. Д., 550 м н. р. м.), лісовий заказник «Потоки», } \\
\text { буковий ліс }\end{array}$ \\
\hline Л2 & 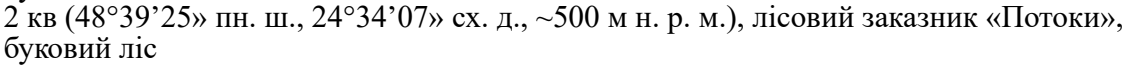 \\
\hline Л3 & $\begin{array}{l}3 \text { кв (48³9’16» пн. ш., 24³4’41» сх. д., 500 м н. р. м.), лісовий заказник «Потоки», } \\
\text { буковий ліс }\end{array}$ \\
\hline Л4 & $\begin{array}{l}6 \text { кв (4839’10» пн. ш., 243’’35» сх. д., } 550 \text { м н. р. м.), лісовий заказник «Потоки», } \\
\text { буковий ліс }\end{array}$ \\
\hline Л5 & $\begin{array}{l}6 \text { кв (48³8’53» пн. ш., 24³3’49» сх. Д., } \sim 450 \text { м н. р. м.), заповідне урочище «Букове», } \\
\text { буковий ліс }\end{array}$ \\
\hline Л6 & $\begin{array}{l}5 \text { кв (48`39’08» Пн. ш., 24³4’15» сх. Д., } 450 \text { м н. p. м.), лісовий заказник «Потоки», } \\
\text { широколистяний ліс із переважанням Carpinus, Acer, Quercus, Prunus, Fagus }\end{array}$ \\
\hline Л7 & $\begin{array}{l}6 \text { кв (48॰39’09» пн. ш., 24³4’19» сх. Д., 550 м н. р. м.), заповідне урочище «Букове», } \\
\text { буковий ліс }\end{array}$ \\
\hline Л8 & $\begin{array}{l}8 \text { кв (48॰38’32» пн. ш., 24³3’24» сх. Д., } 550 \text { м н. р. м.), поблизу руїн гірськолижних } \\
\text { трамплінів, старий буковий ліс }\end{array}$ \\
\hline Л9 & $\begin{array}{l}8 \text { кв (48॰38’43» пн. ш., 24³3’08» сх. д., } 550 \text { м н. р. м.), молодий березовий ліс із } \\
\text { домішкою Alnus, Acer, Larix }\end{array}$ \\
\hline Л10 & $\begin{array}{l}5 \text { кв (48³8'59» пн. ш., 24³3'51» сх. д., } \sim 500 \text { м н. р. м.), лісовий заказник «Потоки», } \\
\text { широколистяний ліс із переважанням Carpinus, Acer, Quercus, Prunus, Fagus }\end{array}$ \\
\hline Л11 & $\begin{array}{l}8 \text { кв }\left(48^{\circ} 38^{\prime} 30 » \text { пн. ш., } 24^{\circ} 33^{\prime} 00 » \text { »х. д., } \sim 550 \text { м н. р. м. }\right) \text {, буковий ліс із домішкою } \\
\text { Quercus, Larix }\end{array}$ \\
\hline Л12 & 8 кв (4838’44» пн. ш., 243’10» сх. д., 550 м н. р. м.), старий буковий ліс \\
\hline Л13 & 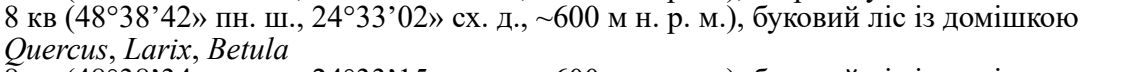 \\
\hline Л14 & $\begin{array}{l}8 \text { кв }\left(48^{\circ} 38^{\prime} 34 » \text { пн. ш., 2433’15» сх. д., } 2600 \text { м н. р. м.), буковий ліс із домішкою }\right. \\
\text { Quercus, Larix }\end{array}$ \\
\hline Л15 & $\begin{array}{l}8 \text { кв (48³8’47» пн. ш., 243’29» сх. д., } 450 \text { м н. р. м.), широколистяний ліс із } \\
\text { переважанням Carpinus, Acer, Quercus, Prunus, Fagus }\end{array}$ \\
\hline
\end{tabular}




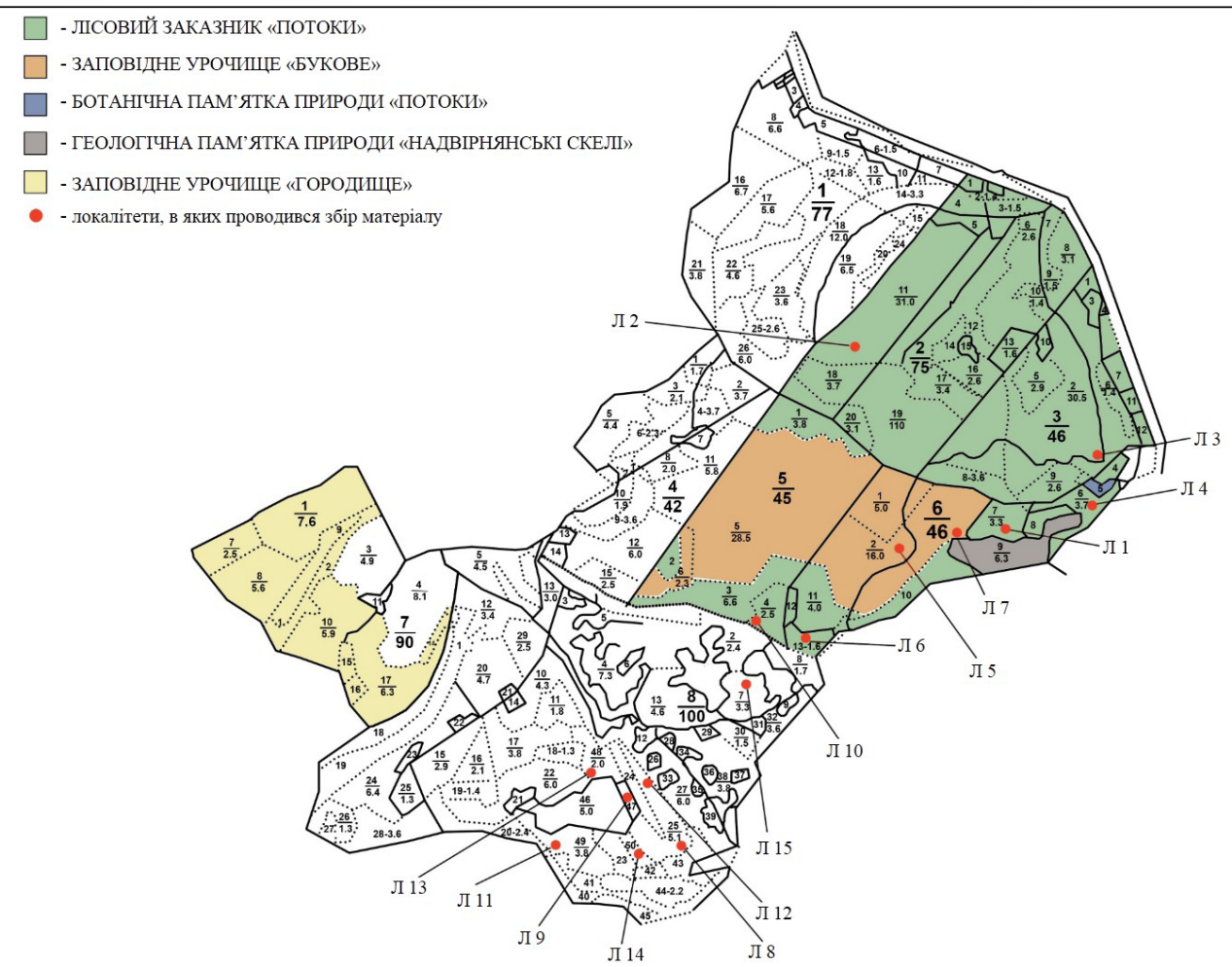

Карта природоохоронних територій 1-8 кварталів Надвірнянського лісництва та локалітетів, у яких проводився збір матеріалу

Камеральну обробку зібраного матеріалу проводили на базі кафедри біології рослин Київського національного університету імені Тараса Шевченка та відділу мікології Інституту ботаніки ім. М.Г. Холодного НАНУ згідно із загальноприйнятими методиками мікологічних досліджень, з використанням відповідних визначників, монографій і атласів українських та зарубіжних авторів. Сучасні латинські назви виявлених видів подано відповідно до бази даних Catalogue of Life (www.catalogueoflife.org).

Для виготовлення препаратів використовували $3 \%$ розчин гідроксиду калію $(\mathrm{KOH})$, реактив Мельцера, аміачний розчин Конго червоного (за Райтвіром) і Лактофенол бавовняно-синій (Lactophenol Cotton Blue - LPCB). Для вивчення морфологічної структури й анатомічних особливостей використовували світловий мікроскоп Ulab XYB2T (об'єктиви 10; 40; 100) та камеру Canon PC 1089 Powershot G6. Під час вимірювання розмірів морфологічних структур використовували програму AxioVision Rel. 4.8 (Carl Zeiss Imaging Solutions, Німеччина).

\section{Результати і їхнє обговорення}

У результаті проведених мікологічних досліджень на території лісового масиву виявлено 107 видів грибів і грибоподібних організмів, що належать до 92 родів, 49 родин, 21 порядку, 7 класів і 3 відділів. Усі види наводяться для дослідженої території вперше.

Абсолютна більшість зареєстрованих нами видів (74 види) є грибами, що трапляються на деревному субстраті. Серед сумчастих грибів (12 видів) переважають ксилотрофні дискоміцети з порядків Helotiales (Ascocoryne cylichnium (Tul.) Korf, Bisporella citrina (Batsch) Korf \& S.E. Carp., Chlorociboria aeruginascens (Nyl.) Kanouse ex C.S. Ramamurthi, Korf \& L.R. Batra, Lachnum virgineum (Batsch) P. Karst.) Ta Pezizales (Trichophae- 
opsis bicuspis (Boud.) Korf \& Erb, Sarcoscypha austriaca (O. Beck ex Sacc.)). Поширені на цьому субстраті також піреноміцети з порядку Xylariales (Biscogniauxia nummularia (Bull.) Kuntze, Diatrype stigma (Hoffm.) Fr., Hypoxylon fragiforme (Pers.) J. Kickx, H. rubiginosum (Pers.) Fr., Xylaria polymorpha (Pers.) Grev.) та Hypocreales (Nectria cinnabarina (Tode) Fr., також і в стадії анаморфи Tubercularia vulgaris Tode). Окрім цього, нами був зареєстрований гіфоміцет невизначеного систематичного положення Bactridium flavum Kunze.

Серед представників відділу Basidiomycota, що ростуть на деревному субстраті (61 вид), очікувано переважають афілофороїдні гриби (51 вид), більш ніж половина яких належить до порядку Polyporales (Anomoporia bombycina (Fr.) Pouzar, Antrodia albida (Fr.) Donk, Antrodiella serpula (P.Karst.) Spirin \& Niemelä, Bjerkandera adusta (Willd.) P.Karst., Cerioporus mollis (Sommerf.) Zmitr. \& Kovalenko, C. varius (Pers.) Zmitr. \& Kovalenko, Cerrena unicolor (Bull.) Murrill, Daedaleopsis tricolor (Bull.) Bondartsev \& Singer, Daedalea quercina (L.) Pers., Fomes fomentarius (L.) Fr., Fomitopsis betulina (Bull.) B.K.Cui, M.L.Han \& Y.C.Dai, F. pinicola (Sw.) P. Karst., Ganoderma applanatum (Pers.) Pat., Irpex lacteus (Fr.) Fr., Ischnoderma resinosum (Schrad.) P. Karst., Laetiporus sulphureus (Bull.) Murrill, Lenzites betulina (L.) Fr., Neofavolus alveolaris (DC.) Sotome \& T. Hatt., Panus neostrigosus DrechslerSantos \& Wartchow, Phlebia radiata Fr., Ph. tremellosa (Schrad.) Nakasone \& Burds., Pycnoporus cinnabarinus (Jacq.) P. Karst., Skeletocutis nivea (Jungh.) Jean Keller, Trametes gibbosa (Pers.) Fr., T. hirsuta (Wulfen) Lloyd, T. versicolor (L.) Lloyd, Xenasmatella vaga (Fr.)). Інші представники групи афілофороїдних грибів належать до порядків Hymenochaetales (Hymenochaete cinnamomea (Pers.) Bres., H. rubiginosa (Dicks.) Lév., Lyomyces crustosus (Pers.) P. Karst., Porodaedalea pini (Brot.) Murrill, Schizopora paradoxa (Schrad.) Donk, Trichaptum biforme (Fr.) Ryvarden, Stalpers, Xylodon raduloides Riebesehl \& Langer), Agaricales (Chondrostereum purpureum (Pers.) Pouzar, Fistulina hepatica (Schaeff.) With., Radulomyces confluens (Fr.) M.P. Christ., R. molaris (Chaillet ex Fr.) M.P. Christ., Schizophyllum commune Fr.), Russulales (Artomyces pyxidatus (Pers.) Jülich, Gloeocystidiellum luridum (Bres.) Boidin, Hericium cirrhatum (Pers.) Nikol., H. coralloides (Scop.) Pers., Peniophora laeta (Fr.)), Auricilariales (Auricularia auricula-judae (Bull.) Quél., A. mesenterica (Dicks.) Pers., Exidia nigricans (With.) P.Roberts), Corticiales (Vuilleminia coryli Boidin, Lanq. \& Gilles) та Trechisporales (Trechispora mollusca (Pers.) Liberta) класу Agaricomycetes. Також ми виявили одного представника порядку Dacrymycetales класу Dacrymycetes - Calocera cornea (Batsch) Fr. та представника порядку Tremellales класу Tremellomycetes - Tremella mesenterica Retz.

Ідентифіковані агарикоїдні гриби (всього 10 видів), що використовують як субстрат деревину і є типовими ксилотрофами - представники порядку Agaricales класу Agaricomycetes: Crepidotus applanatus (Pers.) P. Kumm., Flammulina velutipes (Curtis) Singer, Hymenopellis radicata (Relhan) R.H. Petersen, Hypholoma lateritium (Schaeff.) P. Kumm., Mucidula mucida (Schrad.) Pat., Mycena haematopus (Pers.) P. Kumm., Panellus stipticus (Bull.) P. Karst., Pleurotus ostreatus (Jacq.) P. Kumm., P. pulmonarius (Fr.) Quél., Pluteus cervinus (Schaeff.) P. Kumm.

Оскільки деревостани більшості локалітетів відзначаються домінуванням бука європейського, саме деревина останнього найчастіше виступала субстратом для розвитку більшості видів. Так, на деревині Fagus sylvatica ми виявили шість збудників бурої гнилі (Anomoporia bombycina, Antrodia albida, Daedalea quercina, Fomitopsis pinicola, Ischnoderma resinosum, Laetiporus sulphureus), 11 збудників м'якої гнилі (Ascocoryne cylichnium, Biscogniauxia nummularia, Bisporella citrina, Chlorociboria aeruginascens, Diatrype stigma, Hypoxylon fragiforme, H. rubiginosum, Lachnum virgineum, Trichophaeopsis bicuspis, Sarcoscypha austriaca, Xylaria polymorpha) та 51 збудник білої гнилі (Antrodiella serpula, Artomyces pyxidatus, Auricularia auricula-judae, A. mesenterica, Calocera cornea, Cerioporus mollis, C. varius, Cerrena unicolor, Chondrostereum purpureum, Crepidotus applanatus, 
Daedaleopsis tricolor, Exidia nigricans, Fomes fomentarius, Ganoderma applanatum, Gloeocystidiellum luridum, Hericium cirrhatum, H. coralloides, Hymenochaete cinnamomea, H. rubiginosa, Hymenopellis radicata, Hypholoma lateritium, Irpex lacteus, Lenzites betulina, Lyomyces crustosus, Mucidula mucida, Mycena haematopus, Neofavolus alveolaris, Panellus stipticus, Panus neostrigosus, Peniophora laeta, Phlebia radiata, Ph. tremellosa, Pleurotus ostreatus, P. pulmonarius, Pluteus cervinus, Porodaedalea pini, Pycnoporus cinnabarinus, Radulomyces confluens, $R$. molaris, Schizophyllum commune, Schizopora paradoxa, Skeletocutis nivea, Trametes gibbosa, T. hirsuta, T. versicolor, Trechispora mollusca, Tremella mesenterica, Trichaptum biforme, Vuilleminia coryli, Xenasmatella vaga, Xylodon raduloides). Таким чином, на деревині бука загалом виявлено 68 видів гнилі.

На деревині Carpinus betulus було знайдено по одному збуднику бурої (Laetiporus sulphureus) та м'якої гнилі (Sarcoscypha austriaca), а також шість збудників білої гнилі (Artomyces pyxidatus, Bjerkandera adusta, Hericium cirrhatum, Schizophyllum commune, Trametes versicolor, Xylodon raduloides). Деревина представників роду Quercus була субстратом для збудників білої (Hymenochaete rubiginosa) та бурої гнилі (Daedalea quercina); на деревині видів роду Acer білу гниль спричиняли Flammulina velutipes та Schizophyllum commune, буру - Fistulina hepatica; на деревині Prunus avium виявлено по одному збуднику білої (Daedaleopsis tricolor) та бурої (Fomitopsis pinicola) гнилі. Збудники білої гнилі Porodaedalea pini та Vuilleminia coryli, а також бурої гнилі Fomitopsis betulina виявлені на деревині представників родів Larix, Corylus і Betula відповідно.

Додатково нам вдалось ідентифікувати 12 видів грибів-мікоризоутворювачів (Amanita muscaria (L.) Lam., A. rubescens Pers., A. vaginata (Bull.) Lam., Boletus edulis Bull., B. reticulatus Schaeff., Butyriboletus appendiculatus (Schaeff.) D.Arora \& J.L.Frank, Cantharellus cibarius Fr., Hydnum rufescens Pers., Neoboletus erythropus (Pers.) C.Hahn, Leccinellum pseudoscabrum (Kallenb.) Mikšík, Strobilomyces strobilaceus (Scop.) Berk., Suillus grevillei (Klotzsch) Singer). Із групи грунтових і підстилкових сапротрофів було виявлено 9 видів макроміцетів (Clathrus archeri (Berk.) Dring, Clitocybe nebularis (Batsch) P. Kumm., Coprinellus disseminatus (Pers.) J.E.Lange, Cyathus striatus (Huds.) Willd., Humaria hemisphaerica (F.H. Wigg.) Fuckel, Macrolepiota procera (Scop.) Singer, Mutinus caninus (Huds.) Fr., Phallus impudicus L., Psathyrella corrugis (Pers.) Konrad \& Maubl.). Також було відмічено розвиток двох фітотрофних облігатних паразитичних леотіоміцетів - Erysiphe alphitoides (Griffon \& Maubl.) U.Braun \& S.Takam., що масово вражає листки Quercus robur i Q. petraea та Rhytisma acerinum (Pers.) Fr., строми якого розвивалися на листках видів роду Acer.

Протягом мікологічного дослідження території Надвірнянського лісництва нами обстежено залишки кострищ і виявлено 4 представники вузької екологічної групи карботрофних (пірофільних) грибів, зокрема, облігатні карботрофні дискоміцети Peziza echinospora P. Karst., Pyronema domesticum (Sowerby) Sacc., Trichophaea hemisphaerioides (Mouton) Graddon (виявлені на грунті серед кострища) та Anthracobia maurilabra (Cooke) Boud (на грунті й обгорілому пластику серед кострища), а також факультативний карботроф Huтаria hemisphaerica (F.H. Wigg.) Fuckel, що є гумусовим сапротрофом, проте часто трапляється на порушених вогнем ділянках і гнилій деревині. Слід зауважити, що кількість виявлених карботрофних дискоміцетів може слугувати природним індикатором антропогенного тиску на заповідні території [1].

Нами також узагальнено перші відомості про різноманіття грибоподібних організмів відділу Myxomycota на досліджуваній території. Було відмічено трапляння шести видів слизовиків (Fuligo septica (L.) F.H. Wigg., Hemitrichia serpula (Scop.) Rostaf. ex Lister, Lycogala conicum Pers., L. epidendrum (L.) Fr., Metatrichia vesparia (Batsch) Nann.-Bremek. ex G.W.Martin \& Alexop., Reticularia lycoperdon Bull.), що належать до класу Myxomycetes. 
Серед ідентифікованих нами грибів сім видів виявилися рідкісними (табл. 2). Чотири з них (Clathrus archeri, Hericium coralloides, Mutinus caninus i Strobilomyces strobilaceus) занесені до Червоної книги України [16]. Також на дослідженій території зареєстровано три рідкісних види (Butyriboletus appendiculatus, Hericium cirrhatum та Ischnoderma resinosum), занесені до червоних списків різних країн, відповідно до Compiled European Red List of the European Council for the Conservation of Fungi (http://www.wsl.ch/eccf/candlist-subtotals.xls). За літературними даними $[15,16,18]$, два останніх із них $є$ індикаторами фітоценозів, що мають природоохоронну цінність. Нижче наводимо стислу інформацію про ці види.

Таблиця 2

Рідкісні види грибів, виявлених на території 1-8 кварталів Надвірнянського лісництва

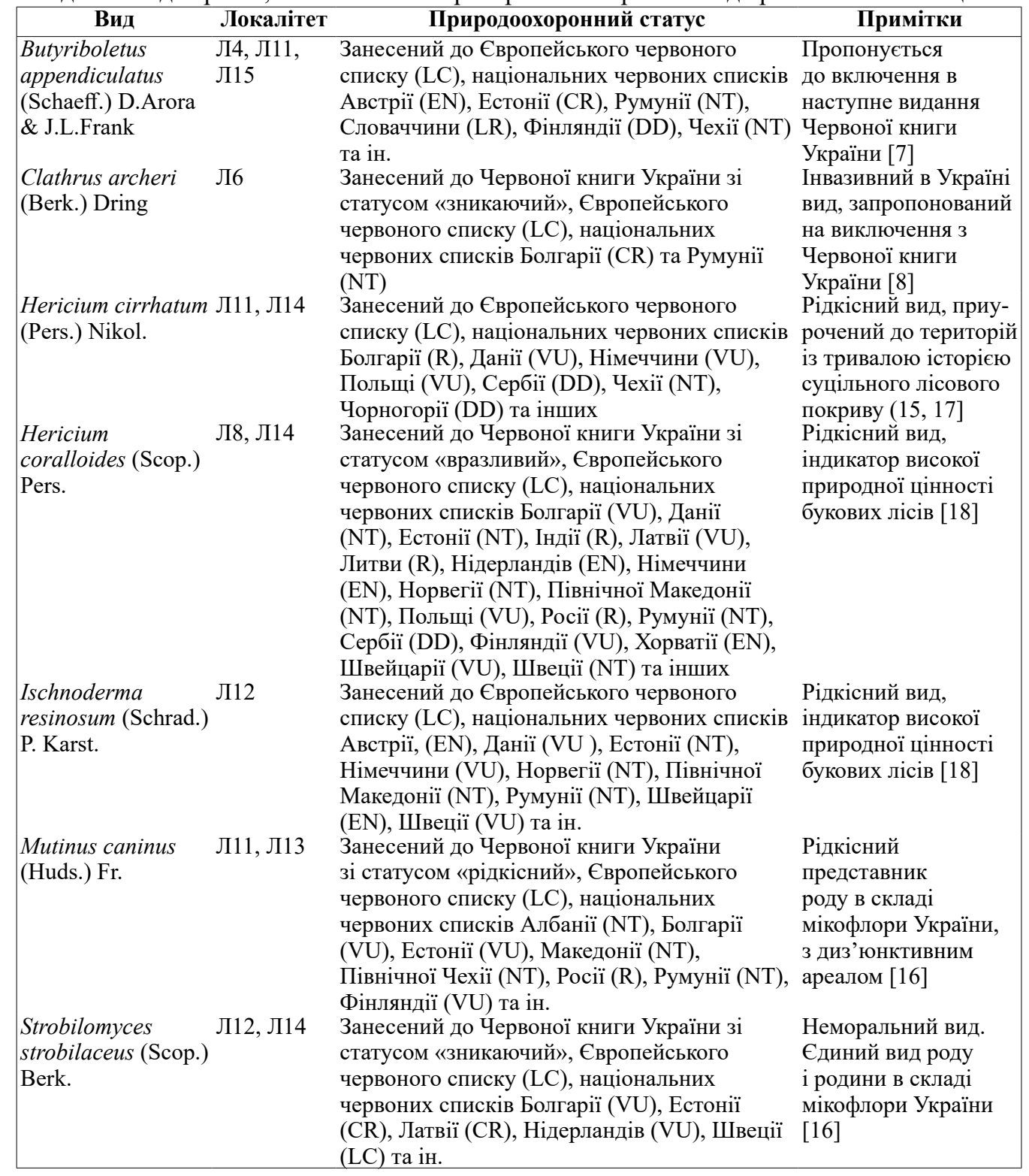


Варто зазначити, що частину видів, які мають природоохоронне значення, знайдено за межами наявних об'єктів ПЗФ. Так, два види, що є індикаторами букових лісів і мають високу природну цінність, знайдені на території 8 кварталу на ділянках, що піддаються значному рекреаційному навантаженню. Зокрема, занесений до Червоної книги України Hericium coralloides був знайдений поблизу стежки, що веде на вершину гори Городище, а рідкісний трутовик Ischnoderma resinosum - біля нещодавно прокладеної траси для гірських велосипедів. Також поблизу зазначеної траси ми зафіксували місцезростання гриба Strobilomyces strobilaceus, що занесений до Червоної книги України [16]. Про зростання антропогенного навантаження на досліджувану територію свідчать також знахідки інвазивного гастероміцета Clathrus archeri, приуроченого до фітоценозів, порушених людиною $[8,10]$. Слід зазначити, що на великій частині досліджуваної території (зокрема, на окремих ділянках лісового заказника "Потоки” та заповідного урочища «Букове») часто трапляються сліди рубок дерев і лісовозної техніки.

У зв’язку з виявленням рідкісних і созологічно цінних видів грибів, що вказують на значну природоохоронну цінність обстежених фітоценозів, і зростанням антропогенного навантаження на досліджуваний лісовий масив, вважаємо доцільним підняти питання про розширення на його території наявної мережі об' єктів ПЗФ, посилення заповідного режиму та контролю за його дотриманням. 3 огляду на те, що обстежена територія характеризується значним різноманіттям не лише мікологічних, а й ботанічних, зоологічних і геологічних об'єктів, що потребують охорони $[2,3,13]$, актуальним є створення на всій території 1-8 кварталів Надвірнянського лісництва регіонального ландшафтного парку «Надвірнянський ліс». Створення такого об’єкта природно-заповідного фонду дасть змогу взяти під охорону значну частину Гвіздського структурно-ерозійного низькогір'я, що поєднує в собі риси як Передкарпатських, так і Гірськокарпатських ландшафтних комплексів [9, 14].

Автори висловлюють подяку професорові В.П. Гелюті й аспірантизі Н.В. Цвид за консультації щзодо визначень, а також Д.В. Бельмезі, М.М. Богославцю, Р.Ю. Богославець, Х.Т. Буній та О.О. Цимовському за допомогу у зборі матеріалу.

\section{СПИСОК ВИКОРИСТАНОЇ ЛІТЕРАТУРИ}

1. Богачева A. В. Дискомицеты заповедников Приморского края: автореф. дис. ... канд. биол. наук: 03.00.24. Владивосток, 1997. 22 с.

2. Бубняк I. М., Солєцький А. Т. Геотуристичний путівник по шляху "Гео-Карпати" Кросно - Борислав - Яремче. Кросно: Державна Вища Професійна Школа імені Станіслава Пігоня в Кросно, 2013. 144 с.

3. Гайдукевич M. С. Дендрофлора Надвірнянського лісництва // Наук. вісн. НЛТУ України. 2012. Вип. 22(11). С. 36-42.

4. Гандзюк Р. Надвірна. Історичний нарис. Івано-Франківськ: Сіверсія, 1999. 276 с.

5. Геоботанічне районування УРСР / Г. Білик, Є. Брадіс, М. Голубець та ін. К.: Наук. думка, 1977. 302 с.

6. Гілецький Й. Р. Природно-географічне районування Українських Карпат як основа оптимізації природокористування у районі // Вісн. наук. праць Чернів. ун-ту. Географія. 2012. Вип. 612-613. С. 28-32.

7. Гелюта В. П. Огляд представників роду Boletus L. як претендентів на включення до «Червоної книги України» // Рослинний світ у Червоній книзі України: впровадження глобальної стратегії збереження рослин: матеріали II Міжнар. наук. конф. (Умань, 2012). Умань, 2012. С. 201-204. 
8. Гелюта В. П., Зикова М. О. Поширення в Україні Clathrus archeri (Phallales, Basidiomycota) - гриба, що має бути виключеним з Червоної книги України // Укр. ботан. журнал. 2018. Т. 75. Вип. 2. С. 137-142.

9. Геренчук К. I. Природа Івано-Франківської області. Львів: Вища школа, 1973. 155 с.

10. Глеб Р. Ю. Поширення квітохвісника (антурус) Арчера (Clathrus archeri (Berk.) Dring., Phallaceae) на території Карпатського біосферного заповідника та прилеглих територіях// Природоохоронні, історико-культурні та екоосвітні аспекти збалансованого розвитку Українських Карпат: матеріали Міжнар. наук.-практ. конф., присв. 15-й річниці НПП «Гуцульщина» (Косів, 2017). Косів, 2017. С. 215-218.

11. Іваненко $C$. I. Аналіз розміщення природно-заповідного фонду України: підхід, стан, проблеми // Укр. геогр. журнал. 2013. № 3. С. 64-69.

12. Клімук Ю., Міскевич У., Якушенко Д. та ін. Природний заповідник «Горгани». Рослинний світ // Природно-заповідні території України. Рослинний світ. Вип. 6. К.: Фітосоціоцентр, 2006. 400 с.

13. Кривко Р., Вереха П. Проект організації розвитку лісового господарства ДП «Надвірнянське ЛГ» Івано-Франківського обласного управління лісового та мисливського господарства. Надвірнянське лісництво. Пояснювальна записка відомості запроектованих заходів. Львів, 2010. 105 с.

14. Мельник А. Українські Карпати: еколого-ландшафтознавче дослідження. Львів, 1999. $288 \mathrm{c}$.

15. Фокшей С. І., Держипільський Л. М. Рідкісні види макроміцетів з урочища Каменистий (Національний природний парк «Гуцульщина») // Укр. ботан. журнал. 2019. Т. 76. Вип. 4. С. 362-366.

16. Червона книга України. Рослинний світ / за ред. Я.П. Дідуха. К.: Глобалконсалтинг, $2009.900 \mathrm{c}$.

17. Boddy L., Crockatt M. E., Ainsworth A. M. Ecology of Hericium cirrhatum, H. coralloides and H. erinaceus in the UK // Fungal Ecology. 2011. Vol. 4. N 2. P. 163-173.

18. Christensen M., Heilmann-Claussen J., Waleyn R., Adamcik S. Wood-inhabiting fungi as indicators of nature value in European beech forests // EFI Proc. 2004. Vol. 51. P. 229-237.

19. Kotiranta H., Niemelä T. Uhanalaiset käävät Suomessa. 2. uudistettu painos. Helsinki, 1996. $184 \mathrm{p}$.

Стаття надійшла до редакиії 11.09.20

доопрацьвована 23.11.20

прийнята до друку 26.11.20 


\title{
THE FIRST DATA ON FUNGAL DIVERSITY OF NADVIRNA FORESTRY (IVANO-FRANKIVSK OBLAST)
}

\author{
O. Bohoslavets ${ }^{1}$, A. Atamanchuk ${ }^{1}$, V. Dzhagan ${ }^{2 *}$, M. Shevchenko ${ }^{1}$
}

\author{
${ }^{I}$ Educational and Scientific Centre Institute of Biology and Medicine \\ Taras Shevchenko National University of Kyiv \\ 64, Volodymyrska St., Kyiv 01601, Ukraine \\ ${ }^{2}$ M.G. Kholodny Institute of Botany, NAS of Ukraine \\ 2, Tereshchenkivska St., Kyiv 01004, Ukraine \\ e-mail:veronika.dzhagan@gmail.com
}

The paper provides the first information about the mycobiota of 1-8 quarters of Nadvirna forestry, located on the slopes of Horodyshche (598 $\mathrm{m}$ above sea level) and Potoky (584 $\mathrm{m}$ above sea level) mountains. As a result of the conducted researches on the territory of the forestry there were revealed 107 species of fungi and fungi-like organisms belonging to 92 genera, 49 families, 21 orders, 7 classes and 3 divisions. All the species are listed for the study area for the first time. Particular attention was paid to wood-inhabiting fungi, of which most of the species (68) were recorded on wood of European beech. Seven species (Butyriboletus appendiculatus (Schaeff.) D.Arora \& J.L.Frank, Clathrus archeri (Berk.) Dring, Hericium cirrhatum (Pers.) Nikol., Hericium coralloides (Scop.) Pers., Ischnoderma resinosum (Schrad.) P. Karst., Mutinus caninus (Huds.) Fr., Strobilomyces strobilaceus (Scop.) Berk.) appeared to be rare for the study area and the territory of Ukraine as a whole. Four of them (Clathrus archeri, Hericium coralloides, Mutinus caninus, Strobilomyces strobilaceus) are listed in the Red Book of Ukraine and three species (Butyriboletus appendiculatus, Hericium cirrhatum and Ischnoderma resinosum) being recorded with the European Red List and red lists of other countries. Hericium cirrhatum and Ischnoderma resinosum are indicator species of phytocenoses that are of conservation value. Upon finding the rare and sozologically valuable species of fungi, indicating the significant conservation value of the surveyed phytocenoses, and the increase of anthropogenic pressure on the studied forest, the expediency of expanding the existing network of protected areas, strengthening the conservation regime and control over its observance is substantiated. As the surveyed area is characterized by a significant variety of not only mycological but also botanical, zoological and geological objects in need of protection, it is proposed to create a regional landscape park "Nadvirnianskyi lis" throughout the massif, which will protect a large part of the Hvizd structural-erosive low mountain massif, which combines the features of both Pre-Carpathian and Mountain Carpathian landscape complexes. servation

Keywords: indicator species, fungal conservation, Red book of Ukraine, nature re- 